\title{
BIOLOGY OF TRIATOMINAE (REDUVIIDAE, HEMIPTERA) FROM NORTH OF FORMOSA COUNTY (GOIAS - BRAZIL) II. LENGTH OF LIFE CYCLE OF RHODNIUS NEGLECTUS LENT, 1954.
}

\author{
Dalva A. Mello*
}

In the present paper the life cycle of Rhodnius neglectus was studied. The mean length from egg to adu/t was 119 days. The mean length in day from aach stage was: 17.4 ( \pm 1.15) for first, $18.2( \pm 1.28)$ for second, 17.7 ( \pm 1.16$)$ for third, $20.3( \pm 1.24)$ for fourth and 29.8 ( \pm 1.46 ) for fifth.

\section{INTRODUCTION}

Rhodnius neglectus, described by Lent in 1954, is a triatomid found in the Brazilian states of Bahia, Minas Gerais, Goiás and São Paulo.

Freitas et $\mathrm{al}^{3}$. studying triatomids in Northeastern São Paulo refer to $R$. neglectus found principally in palm trees (macaúbas). It is rarely found in human dwellings. Barreto et $\mathrm{al}^{1}$, in 1966, studying a population of $T$. cruzi found in a wild environment in Ribeirão Preto County (São Paulo State) also mention finding $R$. neglectus in macaúba palm trees; once it was found in an opossum nest. Lent and Juberg ${ }^{6}$ al so mention that this triatomid is mainly found in wild habitats. For the most part, they are restricted to the crowns of palm trees and a few were found in bird nests of the Furnariidae family or hollow trees.

The role of $R$. neglectus in the transmission of $T$. cruzi is not very clear yet. Pessoa ${ }^{10}$ believes that this species may contribute, directly or indirectly, to the appearance of $T$. cruzi in human beings or domestic animals. Barreto et al $^{1}$. found $4.4 \%$ of captured specimens to be infected with $T$. cruzi. This level may be considered high, since the types of habitats are mainly visited by birds.

The biology of $R$. neglectus was briefly studied for the first time by Dias ${ }^{2}$ in 1955. In
1967, Freitas et $\mathrm{al}^{4}$. carried out a detailed study of several aspects of the biology of this triatomid.

Perlowagora-Szumlewicz et $\mathrm{al}^{8}$. and Perlowagora-Szumlewicz ${ }^{9}$ analysed some aspects of the feeding behavior and biology of $R$. neglectus, comparing it to other species of triatomids.

In order to add more information on the biology of $R$. neglectus to the existing literatu$r e$, the present paper aims at studying, under laboratory conditions, the life cycle of a strain of this triatomid from North of Formosa County, Goiás State.

\section{MATERIALS AND METHODS}

\section{Origin of the population studied}

As in the study of $T$. sordida ${ }^{7}$, the population of $R$. neglectus studied in this paper was originated from a female insect caught in the field, already laying eggs. This female came from a site about $156 \mathrm{~km}$ Northeast of Brazilia, D.F., on the BR-020 highway. This female was found in a wild environment, in a palm crown habitat.

The number of first instar nymphs used for the study of the life sycle corresponded to $82.17 \%$ of the total eggs laid by this female in the laboratory.

* Faculty of Health Sciences University of Brazilia. This work was supported, in part, by a grant of National Research Council of Brazil (SIP/08-032 - CNPq - 6228/75) and the Hinistry of Health.

Submitted to publication on 9. 8. 1976. 


\section{Maintenance of the population}

The population of $R$. neglectus was maintained under the same laboratory conditions as described by Mello ${ }^{7}$ for T. sordida. The temperature and humidity conditions were also the same used by that author, as well as the statistical analyses applied to the results.

\section{RESULTS}

The egg incubation period is shown in table 1. The mean was $16.0( \pm 1.51)$ (table 1) with $98.5 \%$ viable eggs (467 observed and 460 hatched).

The days of occurrence of ecdyses for the five developmental stages of $\boldsymbol{R}$. neglectus are grouped in a class interval as shown in table 2.

The comple te cycle length from egg to adult lasted an average of 119 days.

The female/male ratio was $179 / 159$, a sex ratio of 1.13 .

\section{TABLE 1}

Period of incubation of eggs of $R$. neglectus under laboratory conditions

\begin{tabular}{cc}
\hline $\begin{array}{c}\text { Incubation days } \\
\text { class interval }\end{array}$ & Eggs \\
\hline $5-7$ & 1 \\
$8-10$ & 42 \\
$11-13$ & 63 \\
$14-16$ & 174 \\
$17-19$ & 68 \\
$20-22$ & 89 \\
$23-25$ & 23 \\
\hline No of viable eggs & 460 \\
\hline Viable eggs (\%) & 98.5 \\
\hline Total & 467 \\
\hline
\end{tabular}

\section{COMMENTS}

In his study of the biology of some triatomid species, Dias ${ }^{2}$, in 1955, found that the length of the life cycle of $R$. neglectus, from first instar nymph to adult varied between $\mathbf{9 0}$ and 116 days. Total length for all nymph stages varied from 62 to 76 days while the egg incubation period lasted from 20 to 23 days. They were fed on chicken blood.

Freitas et al. ${ }^{4}$, working at $26^{\circ} \mathrm{C}$ temperature and $75 \%$ relative humidity, observed that the egg incubation period for $R$. neglectus was constant, lasting 15 days. The cycle length from egg to adult lasted 85.9 and 96.7 days, when the insects were fed every 7 and every 14 days, respectively. Mean length for ecdyses in different stages was perceptibly lower when insects were fed every 14 days.

Comparing the data of the above mentioned authors to those obtained in the present study, it was observed that the mean cycle length from egg to adult was closer to those found by Dias ${ }^{2}$ than to those found by Freitas et al. ${ }^{4}$. The length of all developmental stages (Table 2) was longer than that reported by Freitas et al. ${ }^{4}$ in spite of similar temperature, relative humidity and feeding (every 7 days) conditions.

Mortality of $R$. neglectus studied by Freitas et al. $^{4}$ was higher in the third stage, reaching percentages of $22.22 \%$ to $29.17 \%$, respectively, for triatomids fed every 7 and every 14 days. Throughout the entire life cycle, mortality rates were $46.66 \%$ and $36.66 \%$ (insects were fed every 7 and every 14 days on blood).

Although Perlowagora-Szumlewicz ${ }^{9}$ does not present details about the methodology of his work, she refers to a low survival in all nymph stages of $R$. neglectus (46\%). Many adults were incapable of shedding their nymphal cuticle dying with incomplete ecdyses. She also mentioned that of 3,658 eggs observed $84.5 \%$ were viable.

Contrary to the findings of the above mentioned authors, the population of $R$. neglectus studied in the present paper showed low mortality rates (Table 2 and 3 ) and high egg viability, i. e., $98.5 \%$ (Table 1).

Mortality in nymph stages declined (Table 2 and 3), that is, higher in the first stages and decreasing successively. No adult was incapable of freeing itself from the 5th stage cuticle.

Disparities between the results of this study and others may be attributed to striking differences at the population level in the $R$. neglectus species. The population studied has been maintained in the laboratory, up to the present, at a very high numerical level.

\section{ACKNOWLEDGMENTS}

The author thanks Eudmar Curado Lopes for his assistance in laboratory work. 


\section{TABLE 2}

Duration in days of the diferent evolutive stages of $\boldsymbol{R}$. neglectus

\begin{tabular}{lrrrrr}
\hline $\begin{array}{c}\text { Evolutive } \\
\text { Stage } \\
\begin{array}{c}\text { Ecydises } \\
\text { days }\end{array}\end{array}$ & NI & NII & NIII & NIV & NV \\
(class int.) & & & & & \\
\hline $5-7$ & 2 & 0 & 0 & 0 & 0 \\
$8-10$ & 10 & 9 & 10 & 1 & 0 \\
$11-13$ & 38 & 50 & 31 & 17 & 4 \\
$14-16$ & 122 & 101 & 86 & 59 & 5 \\
$17-19$ & 64 & 83 & 138 & 65 & 5 \\
$20-22$ & 48 & 54 & 33 & 92 & 18 \\
$23-25$ & 48 & 55 & 26 & 81 & 24 \\
$26-28$ & 11 & 5 & 6 & 10 & 64 \\
$29-31$ & 8 & 3 & 7 & 7 & 117 \\
$32-34$ & 1 & 0 & 3 & 0 & 43 \\
$35-37$ & 8 & 0 & 1 & 6 & 21 \\
$38-40$ & 0 & 0 & 0 & 1 & 18 \\
$41-43$ & 0 & 0 & 0 & 0 & 12 \\
+44 & 0 & 0 & 0 & 0 & 7 \\
\hline Subtotal & 360 & 349 & 341 & 339 & 338 \\
\hline Dead & 18 & 11 & 8 & 2 & 1 \\
\hline Total & 378 & 360 & 349 & 341 & 339 \\
\hline
\end{tabular}

TABLE 3

Mortality and mean duration of different evolutive stage of $R$. neg/ectus

Evolutive

Stages

Eggs

N I

N 11

N III

N IV

N V
Mean Duration (days)
Mortality \%

Survival \%
$16.0( \pm 1.51)$

$17.4( \pm 1.15)$

$18.2( \pm 1.28)$

$17.7( \pm 1.16)$

$20.3( \pm 1.24)$

$29.8( \pm 1.46)$
4.76

3.05

2.29

0.58

0.29
95.2

96.9

97.7

99.4

99.7 


\section{RESUMO}

Foi estudado no presente trabalho o ciclo biológico de Rhodnius neglectus encontrado no norte do municipio de Formosa, Goiás. A média de duração do ciclo de ovo a adulto foi 119 dias. A média de duração em dias para cada estágio foi: $17.4( \pm 1.15)$ para o primeiro, $18.2( \pm 1.28)$ para o segundo, $17.7( \pm 1.16)$ para o terceiro, $20.3( \pm 1.24)$ para o quarto e 29.8 ( \pm 1.46 ) para o quinto.

\section{REFERENCES}

1. BARRETTO, M. P. SIQUEIRA, A. FERRIOLI, FILHO, F. \& CAVALHEIRO, J.R. - Estudos sobre reservatórios e vectores silvestres do Trypanosoma cruzi XI. Observações sobre um foco natural de tripanossomose americana no município de Ribeirão Preto, S. Paulo Rev. Inst. Med. Trop. S. Paulo 8:103-112, 1966.

2. DIAS, E. - Notas sobre o tempo de evolução de algumas espécies de triatomfneos em laboratório. Rev. Bras. Biol. 15:157-158, 1955.

3. FREITAS, J. L. P. de, SIQUEIRA, A. F. \& FERREIRA, O. A. - Investigações epidemiológicas sobre triatomineos de hábitos domésticos e silvestres com auxílio de reação de precipitina. Rev. Inst. Med. Trop. S. Paulo 2:90-99, 1960.

4. FREITAS, M. G. COSTA, J. O. \& COSTA, H. M. A. - Alguns aspectos de biologia de Rhodnius neglectus Lent, 1954, (HemipteraTriatominae) em condições de laboratório. 1. Evolução. Arq. Esc. Vet. 19:81-87, 1967.

5. LENT, H. Comentários sobre o gênero Rhodnius Stal, com descrição de uma nova espécies no Brasil. Rev. Bras. Biol. 14:237-247, 1954.
6. LENT, H. \& JURBERG, J. - O gênero Rhodnius Stal, 1859, com um estudo sobre a genitalia das espécies (Hemiptera, Reduviidae, Triatominae). Rev. Bras. Biol. 29:487-560, 1969.

7. MELLO, D. A. - Biology of triatominae (Reduviidae, Hemiptera) from North of Formosa County (Goiás-Brazil) II. Length life cycle of Triatoma sordida (Stal, 1859). Em publicação, 1975.

8. PERLOWAGORA-SZUMLEWICZ, A, CRUZ, H. N. da \& ARAUJO, A. N. de Species and Stage interaction in the feeding behavior of vector of Chagas Disease (The importance of determinants in planning for greater efficacy and standardizations of xenodiagnostic proceduras). Rev. Inst. Med. trop. S. Paulo 15:139-150, 1973.

9. PERLOWAGORA-SZUMLEWICZ, A. Laboratory Colonies of Triatomines Biologv and Population Dynamics. Int. Symp. New. App. Amer. Tryp. Res. Belo Horizonte, Brazil 28-21 Marsh, 1975.

10. PESSOA, S. B. - Domiciliação dos triatomíneos e epidemiologia da doença de Chagas. Arq. Hig. S. Paulo 27: 161-171, 1962. 